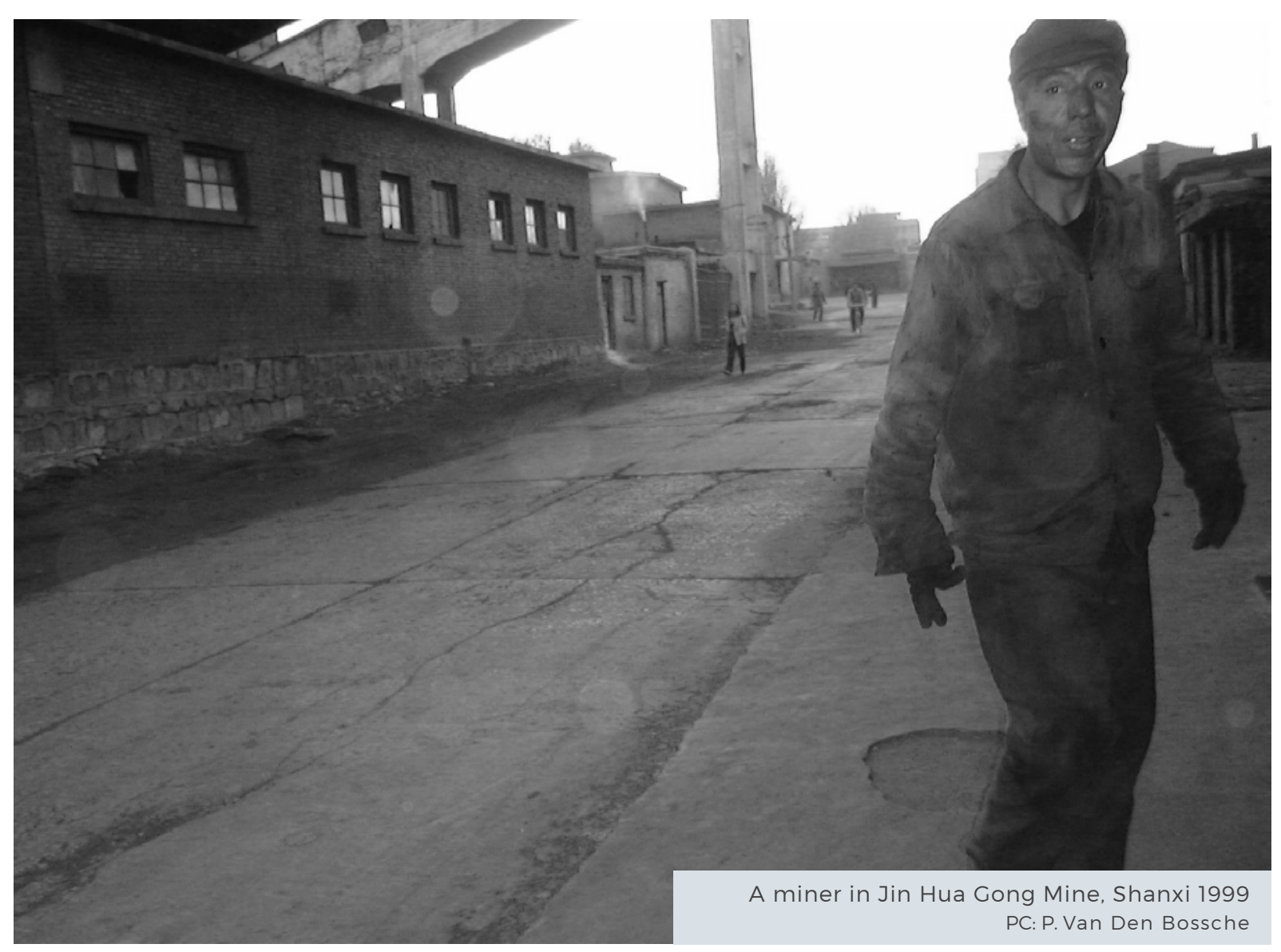

\section{Remoulding the State Sector: Back to the 1990s?}

\section{Kevin Lin}

Recent protests by state workers are once again raising concerns about an increase in labour unrest in the state sector in China. The current surge is reminiscent in many ways of the tumultuous protests that took place at the turn of the century, when the Chinese authorities carried out a drastic restructuring of the economy. The similarity is striking, and the eerily familiar images of protesting state workers only add to the sense of déjà vu. But is history really repeating itself?
In the first quarter of 2016, a week-long strike at an ailing state-owned steel factory in Guangzhou (Denyer 2016a), a street protest by miners in Heilongjiang denouncing the governor for a misleading remark about their wages (Buckley 2016), and a symbolically powerful convergence of coal miners in the once revolutionary area of Anyuan in Jiangxi (Denyer 2016b), have raised concerns that a new wave of protests is likely to take place in the state sector in China.

It has been more than a decade since the last major wave of protests by state workers subsided. Between 1997 and 2003, the state sector shut down and privatised a large number of state factories, leaving between twentyfive and forty million workers temporarily or permanently unemployed, decimating entire working-class communities, and prompting tens of thousands of workers to take to the street (Hurst 2009). 
However, right around the time when China's rural migrant workers in the exportoriented manufacturing sector started to grow restless and more organized in the early 2000s, the resistance of state industrial workers to the marketization of state-owned enterprises (SOEs) suffered a historical defeat (Philion 2009). This was due to a combination of outright suppression, selective compensation, and the gradual winding down of the marketization process.

The current upsurge in many ways evokes memories of the tumultuous wave of protests in the state sector at the turn of the century. The similarity is striking: in the face of falling profitability and a bloated labour force, state workers once again demanded to be paid their proper wages or an adequate severance in the case of layoff. The eerily familiar images of protesting state industrial workers only add to the sense of déjà vu. But is history really repeating itself?

In many respects, the state sector today has been deeply transformed (Hsieh and Song 2015). Decades of reform have converted China's command economy into a modest but strategically significant state sector. The very process that led to the shutting down and sale of factories also brought about a radical restructuring of labour relations and the production process, creating the conditions for a decade of rapid recovery and expansion. This, in turn, has remade SOEs into some of the largest conglomerates in their respective industries, ensuring a decade of relative industrial peace.

\section{After the Global Financial Crisis}

However, early signs of stress appeared soon after the global financial crisis. For a few years, the decline in the growth rate of profits in the state sector was non-threatening. Still, an ideological battle was fought around the idea that further reforms were necessary and desirable (Lin 2013). International financial institutions, mainstream economists, and foreign chambers of commerce, amplified by the media, harshly criticised the inefficiency and corruption of the SOEs and repeatedly advocated for the withdrawal of state subsidies and a further downsizing of the state sector. For a period in late 2015, state sector reforms seemed to be back on the agenda (Bland 2015). However, to the disappointment of critics, the aim of the reforms was to strengthen the sector rather than further privatisation (Wei 2015).

Recently, China's economic predicament has begun to precipitate a widely anticipated crisis of industrial overcapacity (The Economist 2016). Profit margins in the steel industry are surprisingly low, and workers' wages and conditions are very poor at what has been described as zombie economy (Wildau 2016). Steel factories and coal mines are reported to have not been paying wages for months and many workers have already been laid off. When I visited a steel plant in the southern city of Kunming in 2012, I found a factory that was barely surviving on a meagre profit and where workers worked long shifts and earned just above the minimum wage.

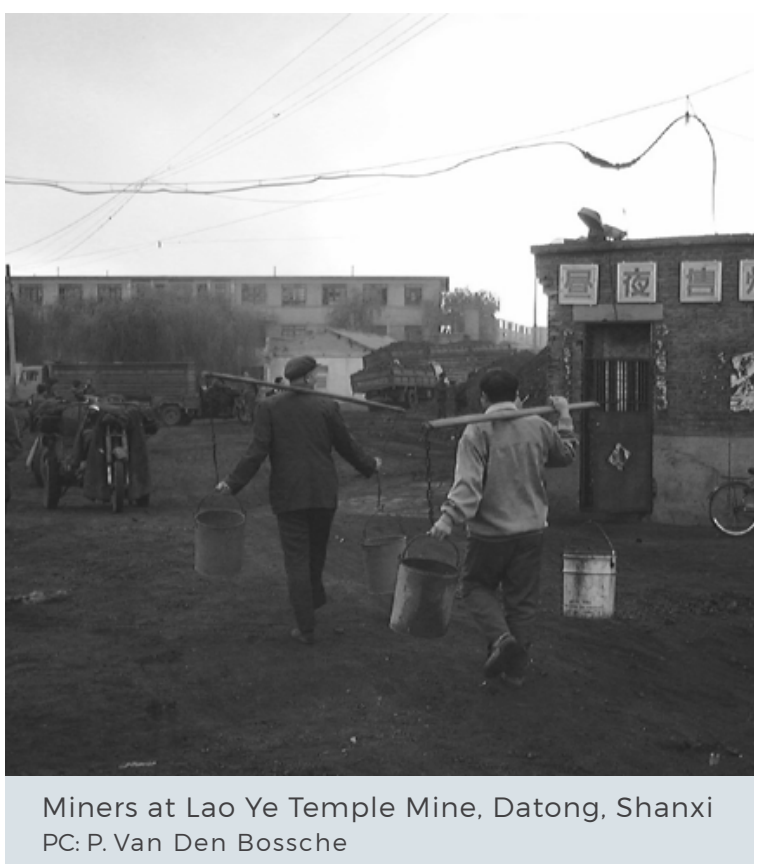


In the last couple of years, there have already been several cases of protests in the state sector (Wong 2015). But it is only now that we are seeing the full extent of the industrial overcapacity and declining profitability in the steel and coal sectors, and the toll that these conditions are taking on the workers. It is, therefore, no wonder that workers are taking collective action. Yet, is this likely to become a repeat of the wave of protests of the late 1990s?

In terms of the scale of the layoffs, whereas in the late 1990s the Chinese authorities targeted SOEs across the board, the current layoffs seem to affect mostly two sectors: steel factories and coal mines (Buckley and Hernandez 2016). There is no evidence that the party-state is interested in an overhaul of the entire state sector like it did two decades ago. The projected layoffs range from 1.8 million workers (about ten percent of the steel workforce and twenty percent of the coal miners) to five or six million (Lim et al. 2016), which are in themselves devastating figures but still pale in comparison to the twentyfive to forty million workers who lost their jobs during the previous wave of reforms. In fact, today the entire state sector-excluding public services such as schools and hospitalsemploys less than forty million workers.

\section{Another Social Volcano in the Making?}

In any event, 1.8 million workers will still be a considerable source of social instability. Moreover, by its very nature the protests in the state sector pose a more direct challenge to the party-state than those in the private sector. To deal with this threat, the Chinese authorities seem to have learned their lessons from the past. They have pre-emptively allocated one hundred billion yuan (about fifteen billion US dollars) to resettle and help laid-off workers find alternative employment.
Yet, although these funds have already been earmarked to compensate laid-off workers, if the recent protests are any indication, managerial irresponsibility and recklessness are a more likely scenario than peaceful settlement. Conflicts at the factory level may still be unavoidable.

Will the layoffs spread to other sectors as a consequence of the deepening economic crisis? This cannot be ruled out. The steel and coal sectors are not the only industries with overcapacity, and there is a chance that the Chinese economy may sharply contract. But thanks to state subsidies, access to state-bank credits, and industrial protection, China's SOEs today are much better equipped than two decades ago to absorb shocks and losses (Zhang 2013). Furthermore, the Chinese state is likely to the fiscal resources to support the state sector and to contain the layoffs to only the designated sectors.

But the protests of state workers are also happening at a particularly fraught time, when tens of thousands of migrant workers in the export sector have been mobilising (Tang 2015), a factor that was much less significant in the late 1990s. This surely has the potential to render the situation more explosive. However, the location of the state sector protests may not significantly overlap with that of the struggles in the export sector. While a recent strike of steel workers did take place in Guangzhou, coal mines and large steel plants tend to be concentrated in inland, northern and north-eastern China instead of the southern coastal regions, a rustbelt/ sunbelt distinction that has remained unchanged for the last two decades (Lee 2007).

Perhaps one of the biggest uncertainties is the disposition of state workers. Who are they? How do they differ from the Maoist state workers? Are they more likely to protest? Over the last two decades, the generations who had any memory of and sentimental attachment to Maoism and who witnessed the wave of layoffs in the 1990s have been largely 
replaced by a younger labour force. As a result of this generational break, state workers may no longer use the Maoist discourse, which was a pivotal part of the protest repertoire for state workers in the earlier waves of unrest.

But state workers today are confronting their own challenges. Two decades of labour intensification, lengthening working hours, and a rising salary gap between workers and management has bred resentment and deep dissatisfaction. As a consequence of the labour reforms, blue-collar state workers may begin to identify themselves with colleagues in the private sector than their predecessors. Perhaps this will become a basis for state workers to begin connecting with their counterparts in non-state sectors, thereby developing a class-consciousness and bridging the labour divide between state and private sector (Hurst 2015; see also the chapter by William Hurst on pp. 16-19 in the present book).

\section{New Challenges, but also Opportunities}

Whether history will repeat itself remains unpredictable. The actions of the Chinese government both at the national and provincial levels will play a fundamental role in shaping the response of the workers. Recent developments such as the attempts to freeze minimum wages and roll back social insurance at the discretion of the provinces and municipalities, as well as the possibility of a watering down of the 'overly protective' Labour Contract Law (see the brief on p. 13 in the present book), will most likely accentuate the damaging effects of the restructuring on workers and possibly ignite more and angrier protests.

For the reasons discussed, this time we are likely to see dynamics at play that are very different from those that characterised the last wave of labour unrest. This should be seen as a positive development. For all of the courage and determination of the state workers involved in these earlier rebellions, it is important to recognise the limitations of these mobilisations. It is undeniable that this will be another difficult time for China's state workers, but the new challenges are also infused with opportunities for the development of a stronger and unified labour movement.

\section{Kevin Lin}

Kevin Lin researches labour politics and civil society in China. His writings are focused on the labour and employment relations in the state-sector, and the development of China's emergent labor movement and its intersection with a nascent civil society. 
This text is taken from Disturbances in Heaven: A Year of Chinese Labour, Civil Society, and Rights, Made in China Yearbook 2016, edited by Ivan Franceschini, Kevin Lin and Nicholas Loubere, published 2017 by ANU Press, The Australian National University, Canberra, Australia. 